\title{
EFFECTS OF STREET FURNITURE TOWARDS THE LESSENING OF PEDESTRIAN AREA IN BRAGA STREET
}

\author{
${ }^{1}$ Dahlia Lubis. ${ }^{2}$ Anindhita N. Sunartio, S.T., M.T. \\ ${ }^{1}$ Student in the Bachelor's (S-1) Study Program in Architecture \\ at Parahyangan Catholic University \\ ${ }^{2}$ Senior lecturer in the Bachelor's (S-1) Study Program in Architecture \\ at Parahyangan Catholic University
}

\begin{abstract}
Bandung has revitalisation plans stretching throughout the city to promote "smart" and "sustainable" living. One of these projects falls on jl. Braga revitalisation project that has shown significant difference in outlook and in visitor count.

The popularity of the street may in return cause discomfort for visitors, as the space allowance per person becomes smaller. This assumption has already been made by Carmona (2003) where he stated that "an unfriendly environment's pedestrian flow may be increased significantly if the space becomes more pedestrian friendly".

The aim of this study is to evaluate the physical changes made by the revitalisation process in correlation to overcrowding. The discussion will begin by identifying elements withing the street that cause obstructions (obstacles), and a simulation of the circulation space acquired by the obstacle (or the activity it generates) is made in order to calculate the resultant circulation space and measure its overcrowding level.

Overall, results show the overcrowding level of the street is constrained and congested. Witihin six out of seven obstructions analysed, it is proved that overcrowding is caused by the acquisition of space of obstacles, whether by itself or by the activities it generates.
\end{abstract}

Key Words: obstacle, obstruction, overcrowding, jl. Braga

\section{DAMPAK PERABOT JALAN TERHADAP TERJADINYA KESESAKAN RUANG PEJALAN KAKI DI JL. BRAGA}

\author{
${ }^{1}$ Dahlia Lubis. ${ }^{2}$ Anindhita N. Sunartio, S.T., M.T. \\ ${ }^{1}$ Mahasiswa S1 Program Studi Arsitektur Universitas Katolik Parahyangan \\ ${ }^{2}$ Dosen Pembimbing S1 Program Studi Arsitektur Universitas Katolik Parahyangan
}

\begin{abstract}
Abstrak- Bandung merencanakan proyek revitalisasi dalam upaya membangun kota "smart" dan berkelanjutan. Salah satu proyek tersebut merupakan revitalisasi jalan Braga yang menunjukkan hasil signifikan berdasarkan kualitas fisik dan jumlah pengunjung.

Ketenaran suatu jalan dapat menyebabkan ketidaknyamanan bagi pengunjung, karena alokasi ruang per orang semakin kecil. Asumsi ini telah dinyatakan oleh Carmona (2003) di mana dia menyatakan bahwa "arus pejalan kaki lingkungan yang tidak nyaman dapat meningkat secara signifikan jika ruang menjadi lebih nyaman".

Tujuan dari penelitian ini adalah untuk mengevaluasi perubahan fisik yang hasil proses revitalisasi yang berkorelasi dengan overcrowding ruang. Pembahasan akan dimulai dengan mengidentifikasi objek pemicu gejala penghambatan (hambatan), dilanjutkan dengan simulasi ruang sirkulasi yang diakuisisi oleh hambatan tersebut (atau kegiatan yang terpicu olehnya), di mana dapat dilakukan perhitungan ruang sirkulasi resultan untuk mengukur tingkat overcrowding ruang jalan.
\end{abstract}

\footnotetext{
${ }^{1}$ Corresponding Author: dahlialubisdahlia@gmail.com
} 
Hasil penelitian menunjukkan bahwa tingkat overcrowding jalan adalan constrained dan congested. Dari total tujuh gejala penghambatan, terbukti bahwa pada 6 gejala overcrowding disebabkan oleh akuisisi ruang hambatan, baik dengan sendirinya atau dengan kegiatan yang dihasilkannya.

Kata Kunci: hambatan, penghambatan, overcrowding, jl. Braga

\section{PENDAHULUAN}

\subsection{REVITALISASI JL. BRAGA}

Bandung sebagai mitra kota kreatif UNESCO telah memulai beberapa proyek dalam wacana pembentukan komunitas dan tata kota berkelanjutan. Dari berbagai proyek tersebut, salah satunya adalah proyek revitalisasi jalan Braga (dengan lokasi Kelurahan Braga, Kecamatan Sumur Bandung, Kota Bandung Jawa Barat), yang selain mengacu pada tujuan tersebut, juga merupakan perbaikan yang dilakukan untuk persiapan komemorasi ulang tahun Konferensi Asia Afrika ke 60.

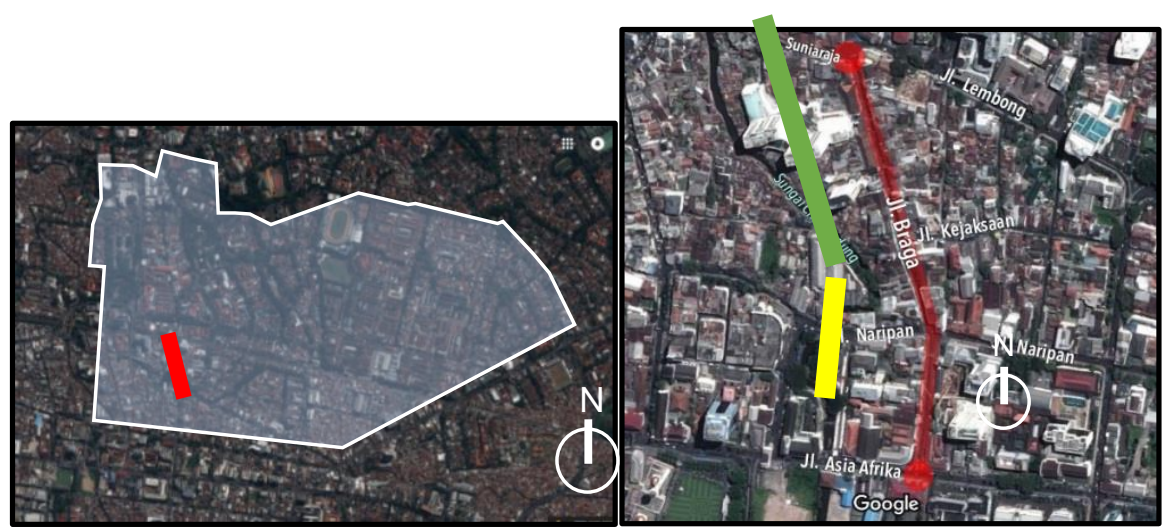

Gambar Error! No text of specified style in document..1. Lokasi objek(kiri, merah) dalam Kecamatan

Coblong (putih), terbagi menjadi Segmen Utara (jingga) dan Segmen Selatan (kuning), dengan jl. Naripan sebagai perempatan pemisah Segmen (Sumber: Google Earth,2016)

Perbaikan Jl. Braga khususnya dilakukan pada segmen utara jalan di mana perbaikan jalan pedestrian untuk mempromosikan pengalaman kota dan kualitas hidup yang lebih baik. Perbaikan tersebut meliputi penambahan ornamen jalan berupa street furniture, perbaikan dan pengubahan material jalur trotoar, dan perbaikan saluran air jalan. Hasil revitalisasi tersebut menunjukkan perubahan pada kualitas ruang dan jumlah pengunjung.

Tabel Error! No text of specified style in document..1. Program-program revitalisasi Jl. Braga pada setting fisik jalan

\begin{tabular}{|c|c|c|c|}
\hline Tahun Pelaksanaan & Program & Stakeholders & Keterangan \\
\hline \multirow{2}{*}{2014} & $\begin{array}{c}\text { Perbaikan trotoar dan } \\
\text { saluran air }\end{array}$ & $\begin{array}{c}\text { Pemerintah Kota } \\
\text { Bandung (Dinas PU) }\end{array}$ & $\begin{array}{c}\text { Perbaikan trotoar } \\
\text { menjadi batu granit. } \\
\text { Penyelenggaraan BCN } \\
\text { setiap 2 minggu 1 kali }\end{array}$ \\
\cline { 2 - 4 } & $\begin{array}{c}\text { Pelestarian bangunan } \\
\text { tua }\end{array}$ & $\begin{array}{c}\text { Pemerintah Kota } \\
\text { Bandung (Distarcip) }\end{array}$ & $\begin{array}{c}\text { Dilakukan pengecetan } \\
\text { terhadap bangunan } \\
\text { sepanjang jalan Braga }\end{array}$ \\
\cline { 2 - 4 } & $\begin{array}{c}\text { Pemasangan bangku } \\
\text { dan ornament hias } \\
\text { (batu huas, tanaman } \\
\text { hias, lampu hias) }\end{array}$ & $\begin{array}{c}\text { Pemerintah Kota } \\
\text { Bandung (Diskamtam) }\end{array}$ & $\begin{array}{c}\text { Pemasangan dilakukan } \\
\text { sebagai penunjang } \\
\text { konsep City Walk }\end{array}$ \\
\hline
\end{tabular}




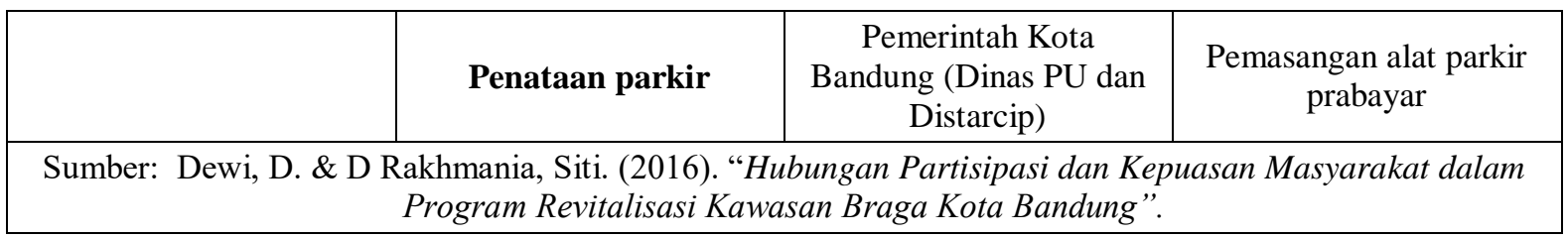

\subsection{FENOMENA GEJALA PENGHAMBATAN PADA RUANG JALAN}

Dalam pengertian kegiatan pada suatu jalur pedestrian, perlu diketahui terlebih dahulu pengertian pedestrian sebagai ruang publik terbuka. Pedestrian merupakan ruang linier yang memicu pergerakan (movement), yang dapat dijelaskan sebagai pola pergerakan yang dinamis. Dalam ruang pedestrian, terdapat 2 kategori kegiatan utama (Moudon, 1987) yaitu kegiatan statis, berupa berdiri, duduk, jongkok, dll., dan kegiatan dinamis, yaitu berjalan.

Hasil survey pada peak hour menunjukkan adanya bentrokan antara dua tipe kegiatan tersebut. Bentrokan tersebut dapat diteliti sebagai suatu gejala penghambatan (obstruction), yang merupakan penghambatan laju jalan per unit jarak pada suatu objek penelitian (Gallin, 2001; Carmona, 2003).

Fenomena tersebut dapat mengakibatkan overcrowding, yaitu tingkat kepadatan pengunjung per unit pedestrian (density) yang melebihi batas tertentu dan menimbulkan ketidaknyamanan. Sebagai penelitian arsitekstural, penelitian ini akan mecari akar gejala penghabatan dengan melihat setting fisik ruang, di mana penataan elemen-elemen jalan memiliki potensi sebagai hambatan (obstacle) yang memicu gejala penghambatan tersebut.

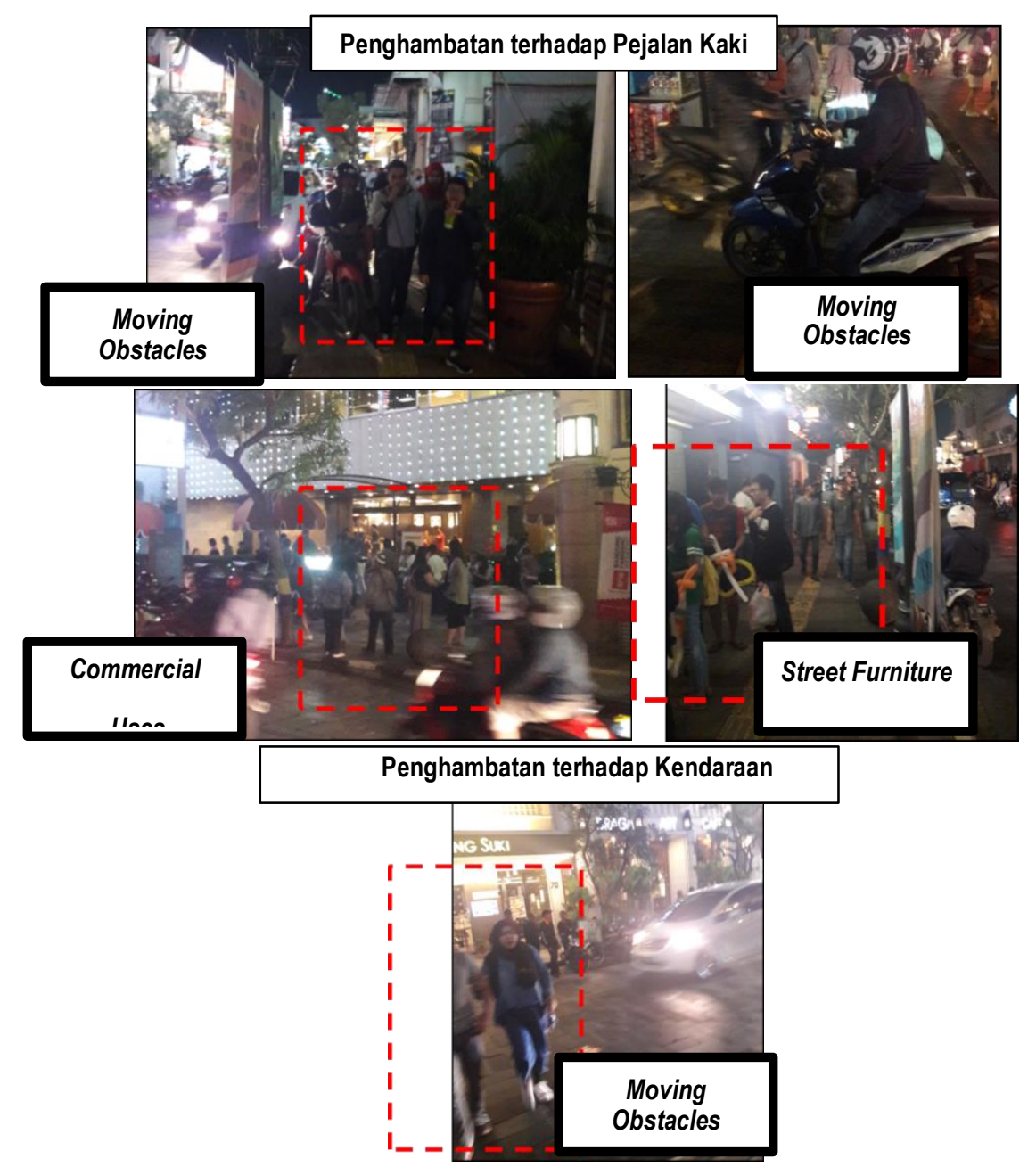


Gambar Error! No text of specified style in document..2 Contoh gejala penghambatan terhadap pejalan kaki ( 2 atas dan 2 tengah) dan kendaraan (bawah)

Tujuan penelitian tentang gejala penghambatan, hambatan pemicu, dan hasil ruang yang terbentuk (apakah terjadinya overcrowding atau tidak) adalah untuk mendeskripsikan hasil revitalisasi yang telah dilaksanakan, di mana didapatkan kritik dan evaluasi terhadap setting fisik yang telah di tata ulang dengan penilaian terhadap kesesuaian penataan terhadap penampungan aktivitas yang terjadi di dalamnya.

\section{KAJIAN TEORI}

\subsection{SETTING FISIK JL. BRAGA UTARA}

Setting fisik yang berpengaruh terhadap terjadinya gejala penghambatan (berdasarkan studi literatur) diantara lain adalah elemen-elemen pembentuk ruang dan frontage bagunan selubung.

\subsection{ELEMEN PEMBENTUK RUANG PADA SEGMEN DP DAN DH}

Setting fisik berupa elemen pembentuk ruang pada Segmen DP dan DH memiliki elemen-elemen tertentu yang tertata dengan pola repetitif (bollard, pohon, lampu) dan beberapa yang hanya dialokasikan di tempat-tempat tertentu (bangku, objek berhubungan dengan fungsi komersil, pot bunga, tempat sampah, dan semua hambatan setting fisik jalan). Lokasi elemen-elemen repetitif terlepas dari bangunan koridor, melainkan dengan elemen yang terletak pada tempat-tempat tertentu yang tidak terlepas dengan fungsi bangunan karena bersifat semi-fixed. Elemen yang terdapat hanya Segmen DH berupa papan informasi directory kawasan.

\section{1 .}

Untuk melihat letak elemen pembentuk ruang pada Segmen DP dan DH, lihat gambar

\subsection{FRONTAGE PADA SEGMEN DP DAN DH}

Segmen DP dan DH memiliki variasi fungsi yang mirip, namun dengan intensitas yang berbeda, di mana pada hanya pada Segmen DP terdapat fungsi kantor dan kafe dan hanya pada Segmen DH memiliki fungsi hotel. Berikut rincian fungsi serta lokasi per Segmen paling menarik.

Tabel Error! No text of specified style in document..2. Legenda fungsi Segmen DP

\begin{tabular}{l|l|l|l|}
\hline Ruas Barat & \multicolumn{2}{l|}{ Ruas Timur } \\
\hline $\mathbf{2 7}$ & Wendy's & A & - \\
\hline $\mathbf{2 8}$ & Starbucks & B & NorthSea/Bragaweg \\
\hline $\mathbf{2 9}$ & Mor & C & Roempoet \\
\hline $\mathbf{3 0}$ & Klab Central & D & Upnormal \\
\hline $\mathbf{3 1}$ & Indosukses & E & Centrin Online \\
\hline $\mathbf{3 2}$ & - & F & Korilurs \\
\hline $\mathbf{3 3}$ & Myllic & G & Omalia \\
\hline $\mathbf{3 4}$ & The Leather Palace & H & Bandung Suki \\
\hline $\mathbf{3 5}$ & Toko Buku & I & Braga Art Cafe \\
\hline
\end{tabular}

Tabel Error! No text of specified style in document..3. Legenda fungsi Segmen DH

\begin{tabular}{|r|r|r|l|}
\multicolumn{2}{|c|}{ Ruas Barat } & \multicolumn{2}{c|}{ Ruas Timur } \\
\hline $\mathbf{1 7}$ & $\begin{array}{l}\text { Golden Sun Marmo } \\
\text { Center }\end{array}$ & J & $\begin{array}{l}\text { Alfa/Braga Punya } \\
\text { Cerita/-/Warung Bebek } \\
\text { Kaleo }\end{array}$ \\
\hline $\mathbf{1 8}$ & Gino Ferruci Hotel & K & Braga Permai \\
\hline $\mathbf{1 9}$ & Warung C'mar & L & La Baraga \\
\hline $\mathbf{2 0}$ & Escobar & M & Indomaret Point \\
\hline $\mathbf{2 1}$ & Art Gallery Djawa & N & - \\
\hline $\mathbf{2 2}$ & Toko Buku Djawa 79 & O & Duta Nada/LG/Samsung \\
\hline $\mathbf{2 3}$ & Sugarush & P & $\begin{array}{l}\text { Wildrose Collection } \\
\text { (Busana) }\end{array}$ \\
\hline $\mathbf{2 4}$ & - & & \\
\hline $\mathbf{2 5}$ & Canon & & \\
\hline $\mathbf{2 6}$ & Circle K & & \\
\hline
\end{tabular}



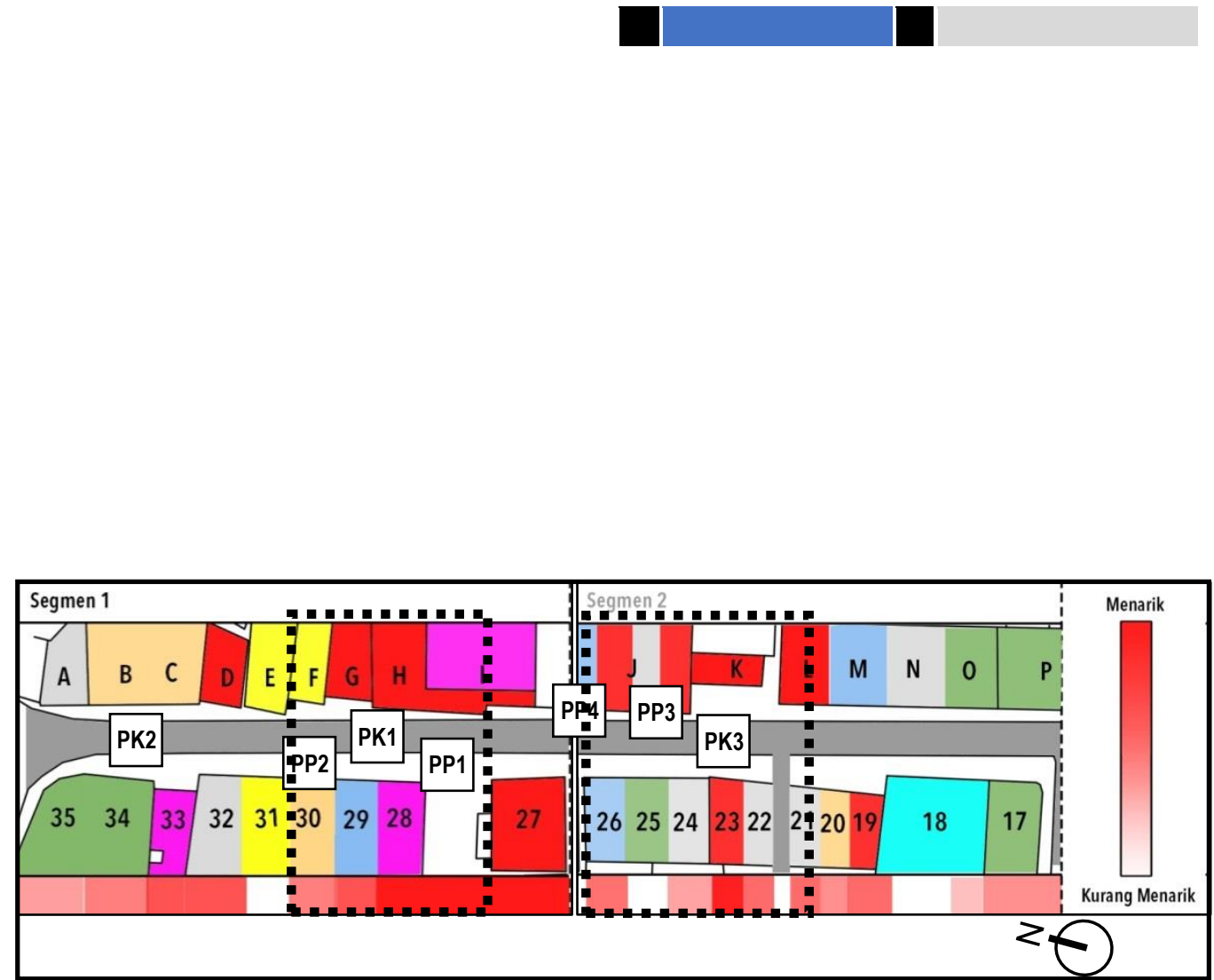

Gambar Error! No text of specified style in document..3. Ketertarikan pengunjung berdasarkan fungsi bangunan dan letak gejala penghambatan. Untuk keterangan fungsi tiap bangunan, lihat tabel 2.1. dan 2.2.

\section{METODA PENELITIAN}

Penelitian ini akan membahas isu overcrowding dengan melihat pengaruh setting fisik sebagai pemicu kegiatan di mana terjadi gejala penghambatan kegiatan dinamis dengan kacamata sebab-akibat. Hasil dari penelitian berupa identifikasi dan evaluasi setting fisik.

Objek penelitian dipersempit menjadi hanya 2 segmen untuk mendapatkan sampel yang dapat mewakili dampak setting fisik terhadap timbulnya overcrowding, yaitu Segmen Dominan Penghambatan (DP) dan Segmen Dominan Hambatan (DH). Kedua segmen memiliki aspek yang dapat mewakili gejala yang terjadi di koridor dengan basis paling banyak gejala penghambatan dan setting fisik paling lengkap secara respektif. Selain itu, waktu observasi ditentukan pada peak hour (17.00 - 21.00) yang didapatkan dari hasil survey awal karena merupakan waktu dengan potensi paling banyak terjadinya gejala penghambatan, sehingga didapatkan variasi sampel gejala dengan kondisi yang konsisten. 


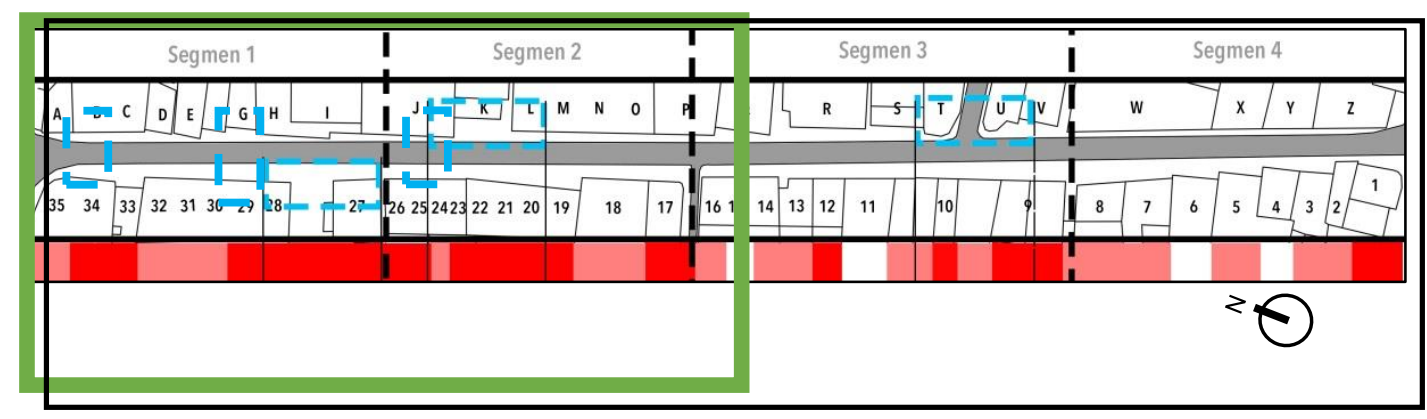

Jumlah Penghambatan $=4 \quad$ Jumlah Penghambatan $=3 \quad$ Jumlah Penghambatan $=1$

Jumlah Penghambatan $=0$

Gambar Error! No text of specified style in document..4Peta koridor jl. Braga Utara dengan pengulangan gejala penghambatan selama 4 survey lapangan (kotak biru). Untuk data kegiatan dan gejala penghambatan per pendataan, lihat Lampiran.

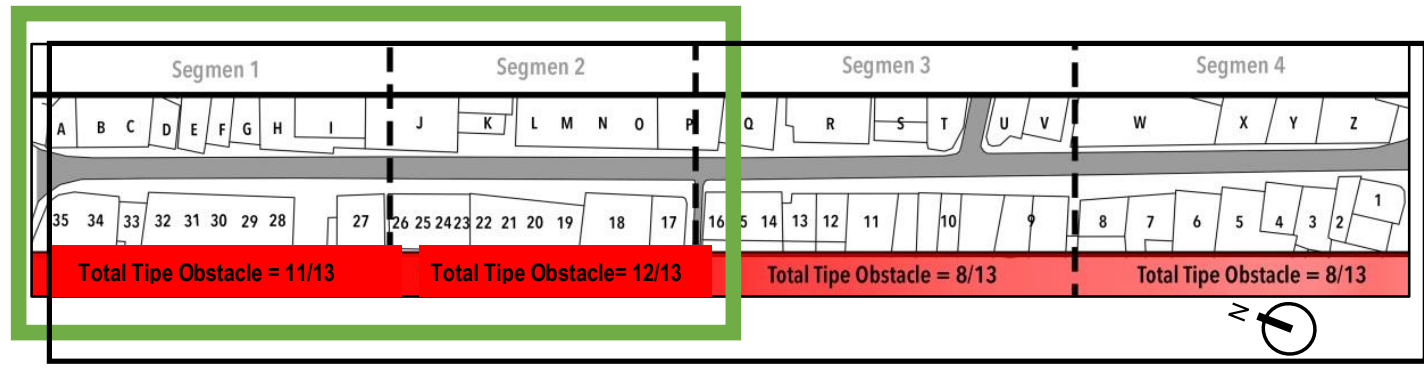

Gambar Error! No text of specified style in document..5. Peta dan tingkat kelengkapan elemen setting fisik hambatan pada tiap segmen. Untuk rincian semua tipe hambatan dan lokasi pada tiap segmen lihat Lampiran.

\section{ANALISA \\ 4.1 KEGIATAN DAN GEJALA PENGHAMBATAN PADA SEGMEN JL. BRAGA UTARA}

Kegiatan yang terjadi pada kedua segmen dapat dikategorikan menurut tipe kegiatan di mana terdapat (1) pola penghambatan pada kegiatan dimanis pedestrian (PP) dengan sub tipe menunggu (PM), menhindar dalam ruang sirkulasi (PDS) dan menghindar keluar sirkulasi (PKS), (2) pola penghambatan pada kegiatan dinamis kendaraan (PK) dengan sub-tipe menunggu (KM) dan menghindar (KDS), (3) pola kegiatan statis dengan sub-tipe duduk sendir (DS) dan berkelompok (DK), berdiri sendiri (BS) dan berkelompok (BK), dan variasi, dan (4) pola kegiatan dinamis. Letak tiap kegiatan dapat dilihat pada peta (gambar 3.1.). 

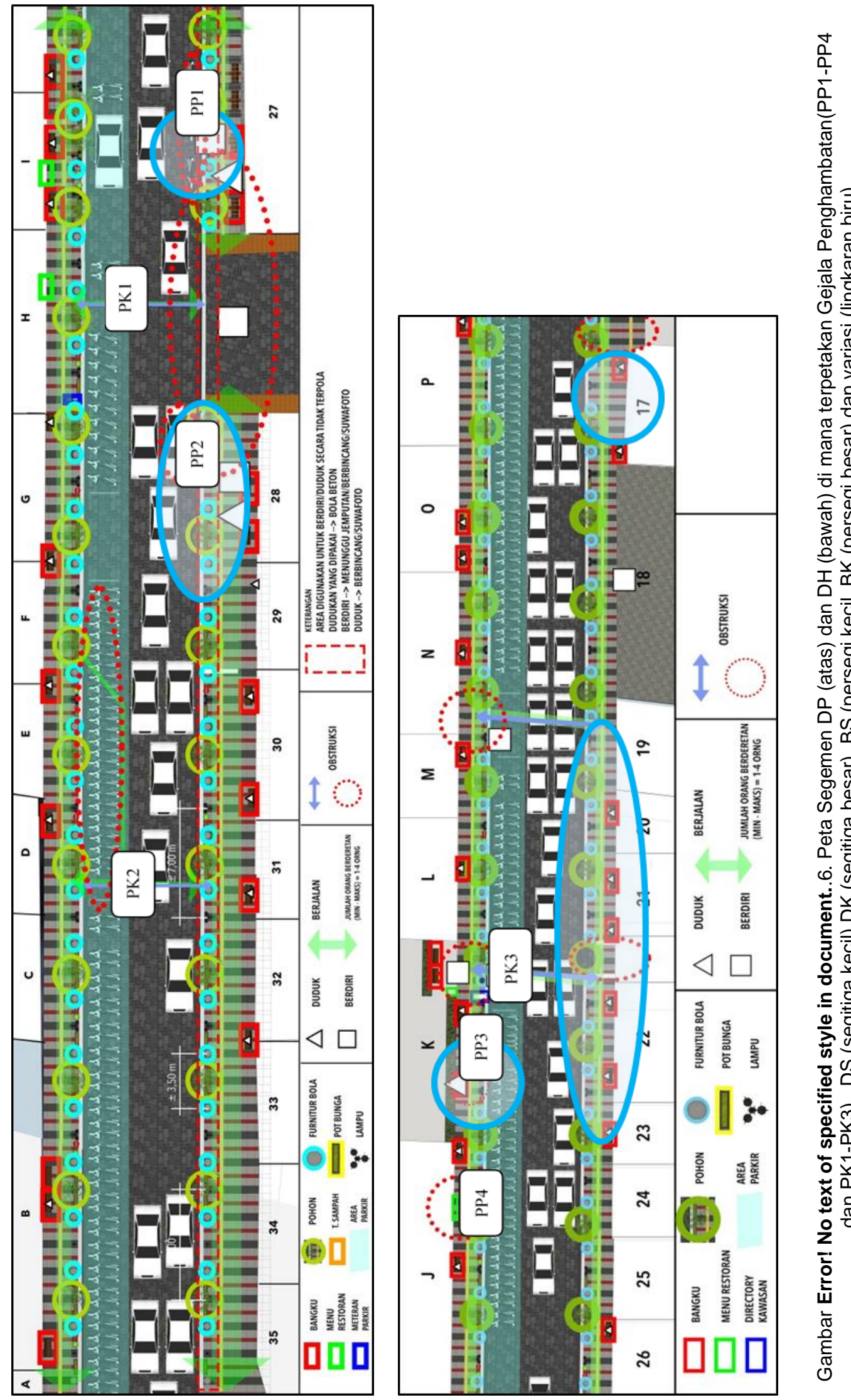

Berikut merupakan rincian tiap Gejala Penghambatan. 

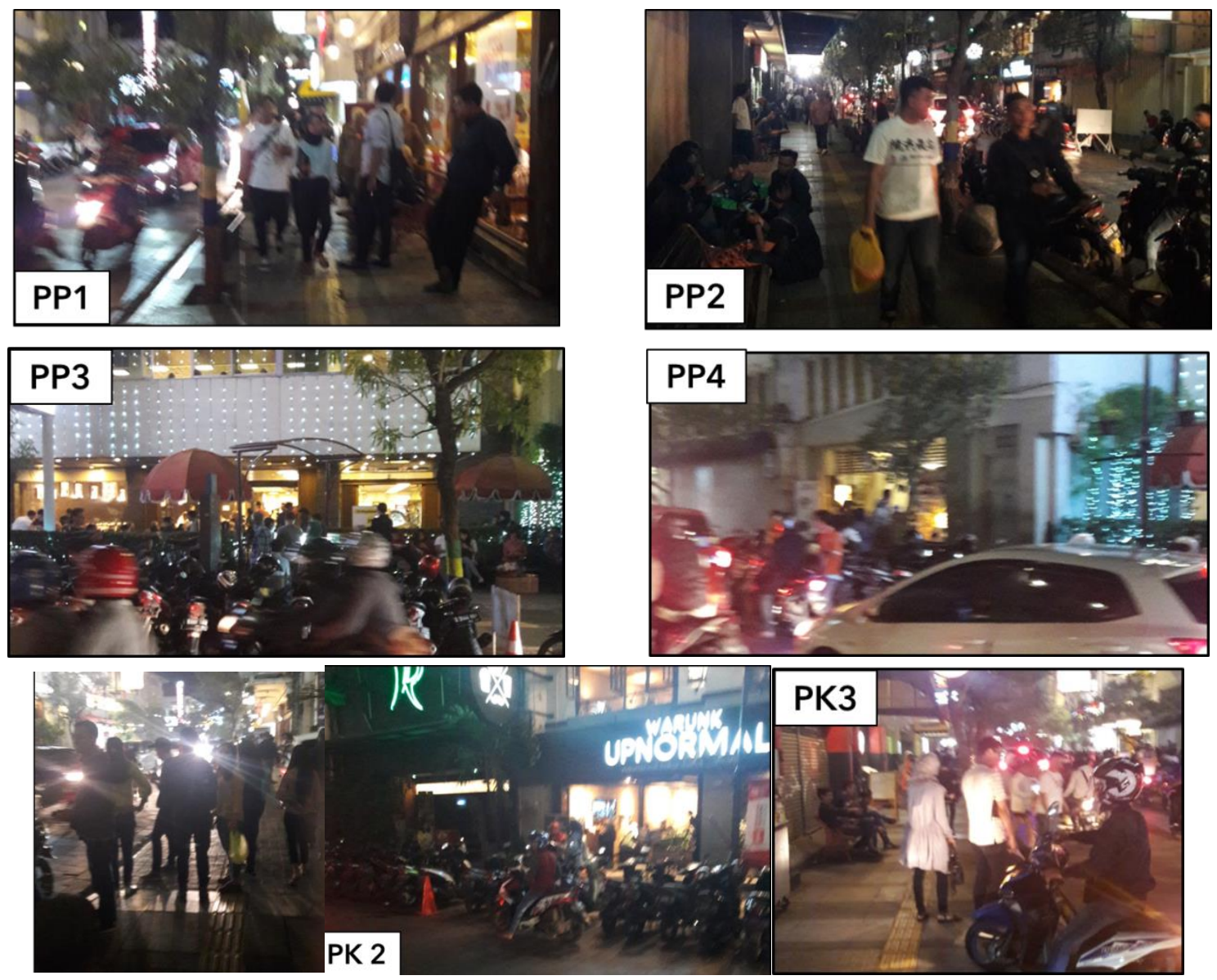

Gambar Error! No text of specified style in document..7. Foto gejala penghambatan PP1-PP4 (atas) dan PK1-PK3 (bawah). Untuk lokasi lihat peta gambar 3.1.

Tabel Error! No text of specified style in document..4. Rincian Gejala Penghambatan PP dan PK

\begin{tabular}{|c|c|l|}
\hline $\begin{array}{c}\text { Gejala } \\
\text { Penghambatan }\end{array}$ & $\begin{array}{c}\text { Sub-Tipe } \\
\text { Penghambatan }\end{array}$ & \multicolumn{1}{c|}{ Letak Spesifik } \\
\hline PP1 & PM, PDS & Pada entrance Braga City Walk, dekat wendys \\
\hline & PKS, PDS & Depan Wendy's \\
\hline PP2 & PDS, PM & Pada entrance Braga City Walk, dekat Starbucks \\
\hline PP3 & PDS & Antara Bollard dan Bangku \\
\hline & PM & Area bangku depan vegetasi Braga Permai \\
\hline PP4 & PM, PDS & Area Direktori Kawasan, menu restoran Braga Permai, area valet parking tanpa mobil \\
\hline PK1 & KM & Area depan menu Bebek Kaleyo \\
\hline PK2 & KM & Area entrance Braga City Walk, jalan antara Braga City Walk dan Suki Bandung \\
\hline & PKS $\rightarrow$ KDS & Area selatan restoran Upnormal \\
\hline PK3 & KM & Area jalan antara Sugarush dan Braga Pernai \\
\hline
\end{tabular}

Pada Gejala Pengahambatan PP1 dan PP2, terjadi penghambatan laju kegiatan dinamis pejalan kaki di mana pejalan kaki harus berhenti dan menunggu (PM), pejalan kaki memasuki area elemen pemisah trotoar dan jalan untuk menghindar (PKS), atau menghindar dalam ruang jalan (PDS) pada ujung dekat dengan entrance mall.

Pada Gejala Pengahambatan PP3, terjadi penghambatan laju kegiatan dinamis pejalan kaki di mana pejalan kaki harus berhenti dan menunggu (PM), pejalan kaki memasuki area elemen pemisah trotoar dan jalan untuk menghindar (PKS), atau menghindar dalam ruang jalan (PDS). Gejala terjadi pada area bangku depan restoran Braga Permai dan dekat directory kawasan di mana terdapat banyak kegiatan statis (BS, BK dan variasi). 
Gambar Error! No text of specified style in document..8. Denah Gejala Penghambatan PP1 (kiri) dan PP2 (kanan), di mana letak pengunjung berdiri (persegi) dan duduk (segitiga) merupakan simulasi berdasarkan hasil pendataan survey
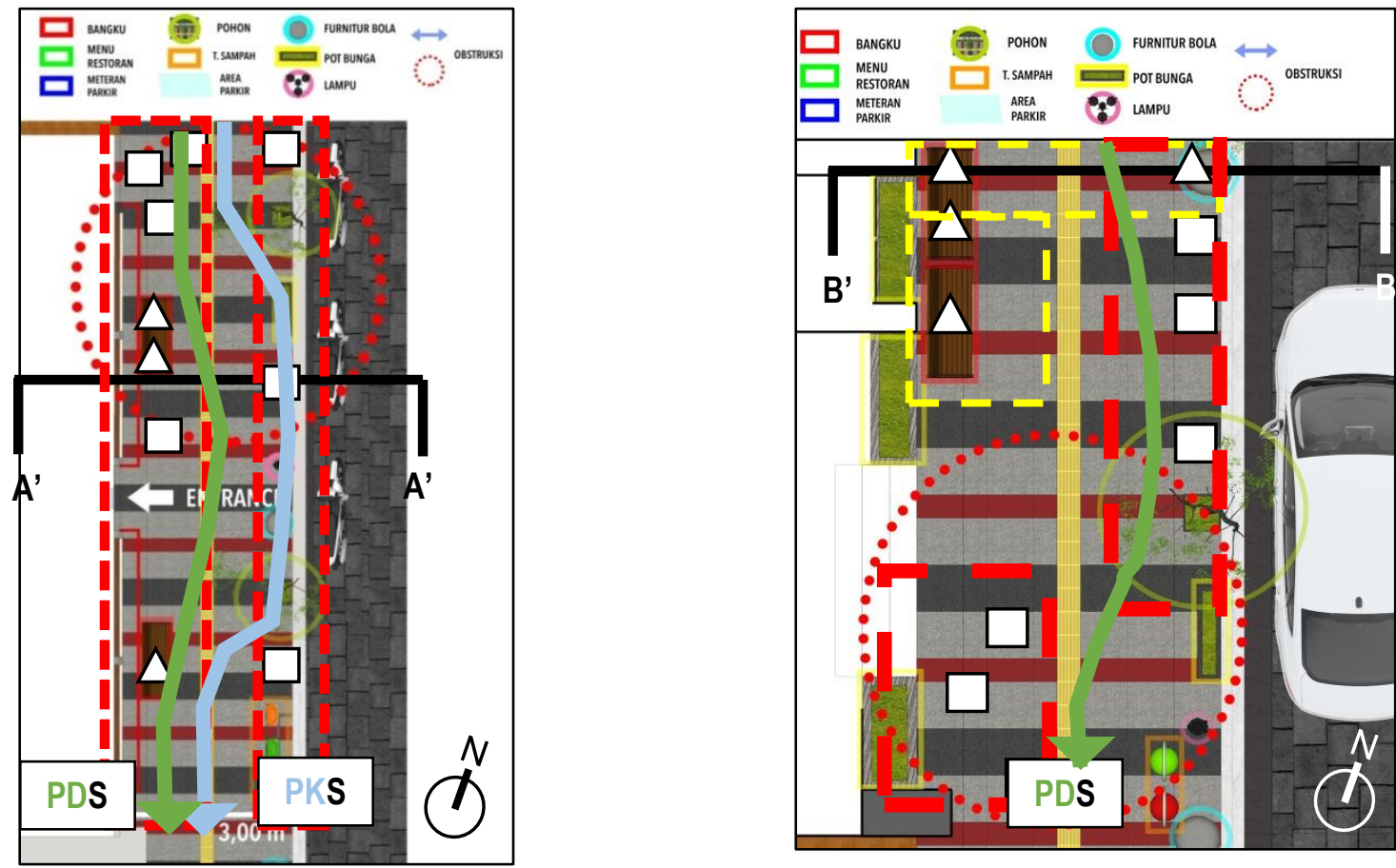

Gambar Error! No text of specified style in document..9. Denah Gejala Penghambatan PP3 dan PK3 (kiri) dan PP4 (kanan), di mana letak pengunjung berdiri (persegi) dan duduk (segitiga) merupakan simulasi berdasarkan hasil pendataan survey
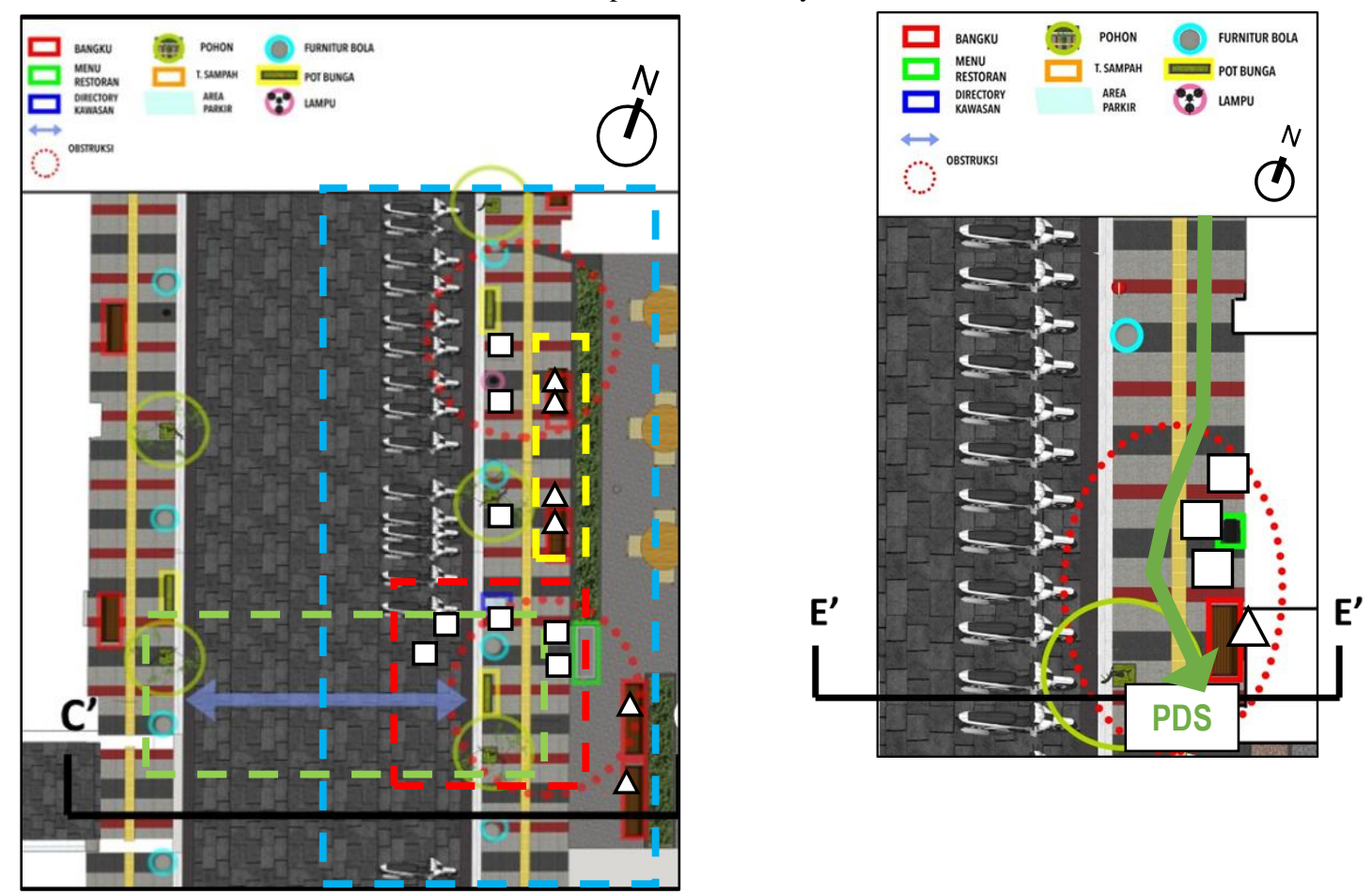
Pada Gejala Pengahambatan PP4, terjadi penghambatan laju kegiatan dinamis pejalan kaki di mana pejalan kaki harus berhenti dan menunggu (PM), atau menghindar dalam ruang jalan (PDS). Kegiatan tersebut adalah untuk menghindar kegiatan statis (BK) yang terjadi depan menu restoran.

Pada Gejala Pengahambatan PK1 dan PK3, terjadi penghambatan laju kegiatan dinamis kendaraan di mana kendaraan harus berhenti dan menunggu (KM). Gejala terjadi pada area jalan antara entrance mall dan Bandung Suki karena banyaknya terjadi penyeberangan pada titik tersebut.

Pada Gejala Pengahambatan PK2, terjadi penghambatan laju kegiatan dinamis pejalan kaki di mana pejalan kaki harus berhenti dan menunggu (KM), atau menghindar dalam ruang jalan (KDS) pada area depan restoran Upnormal karena banyak yang menyebrang pada titik tersebut dan berjalan dari arah selatan pada ruang jalan (PKS).

Gambar Error! No text of specified style in document..10. Denah Gejala Penghambatan PK1 (kiri) dan PK2 (kanan), di mana letak pengunjung berdiri (persegi) dan duduk (segitiga) merupakan simulasi berdasarkan hasil pendataan survey
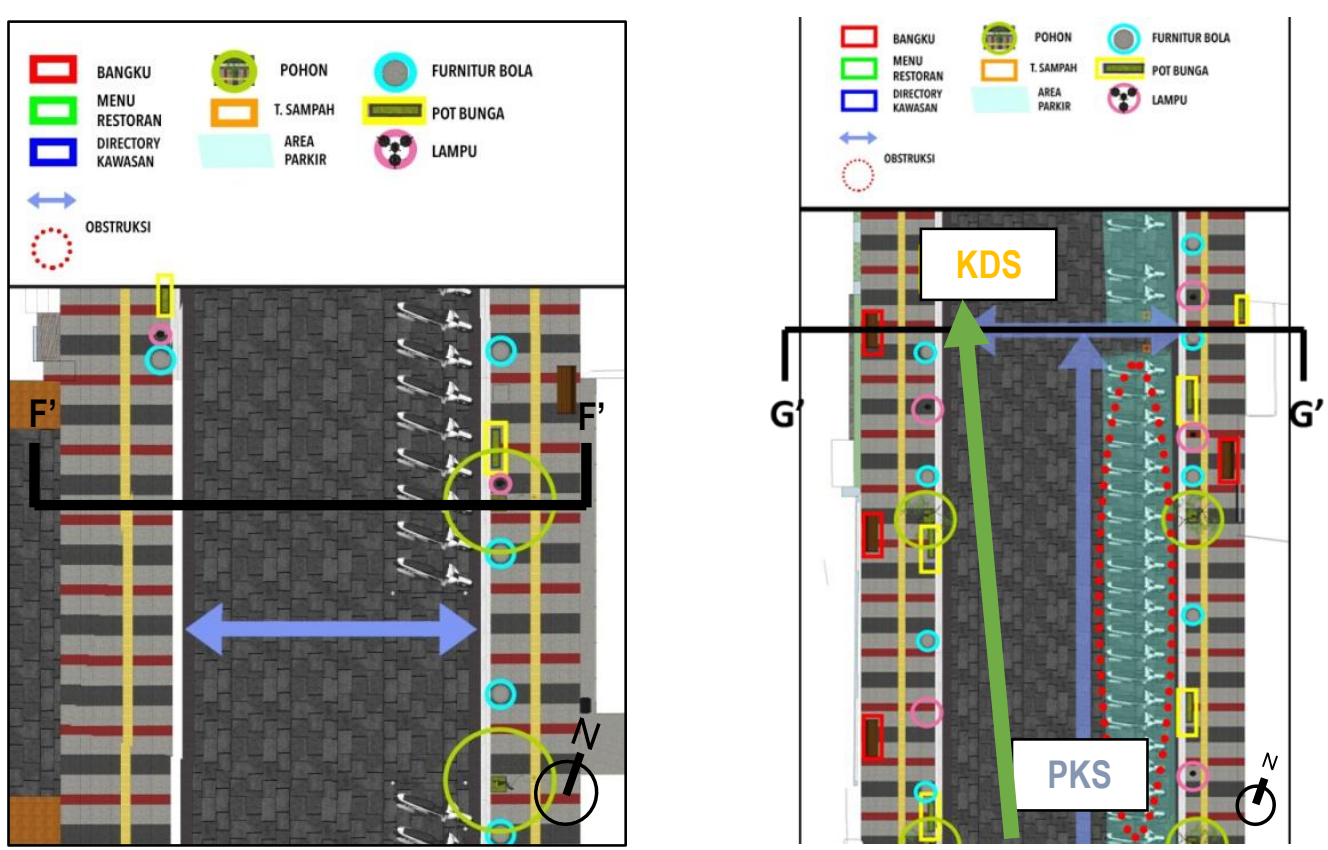

\subsection{IDENTIFIKASI HAMBATAN BERDASARKAN GEJALA PENGHAMBATAN}

Penghambatan pada Gejala Penghambatan PP1 dan PP2 terjadi karena adanya hambatan bergerak berupa pedestrian berdiri (BK), duduk (DK), dan variasi antara keduanya, sehingga pejalan kaki harus menunggu giliran (PM) atau menghindar (PDS dan PKS). Hambatan tersebut terpicu oleh setting fisik, baik frontage bangunan yang menarik keramaian maupun elemen pembentuk ruang, khususnya hambatan berupa street furniture dan hambatan bergerak (informal) yang membentuk ruang sirkulasi alternatif dan benteng fisik dari kegiatan dinamis dan memicu kegiatan statis.

Penghambatan pada Gejala Penghambatan PP3 terjadi karena adanya hambatan bergerak berupa pedestrian berdiri (BK), duduk (DK), dan variasi antara keduanya sehingga pejalan kaki harus menunggu giliran (PM) atau menghindar (PDS). Adanya semua kegiatan tersebut dikarenakan oleh elemen pembentuk ruang yang letakknya terpusat pada area tersebut. Banyaknya elemen mengakibatkan ruang kegiatan saling menumpuk. Oleh karena itu, gejala 
diakibatkan oleh hambatan berupa street furniture dan hambatan berupa penggunaan komersil

Penghambatan pada Gejala Penghambatan PP4 terjadi karena adanya hambatan bergerak berupa pedestrian berdiri (BK), dan berjalan (berlawan arah), sehingga pejalan kaki harus menunggu giliran (PM) atau menghindar (PDS). Adanya semua kegiatan tersebut dikarenakan elemen pembentuk ruang yang letakknya kurang baik, spesifik menu restoran. Menu restoran mengakibatkan orang berdiri dan membaca, mengurangi jalur sirkulasi. Oleh karena itu, gejala diakibatkan oleh hambatan berupa penggunaan komersil.

Gambar Error! No text of specified style in
document..11. Hambatan pada Gejala
Penghambatan PP1 yang memberi dampak secara
tidak langsung

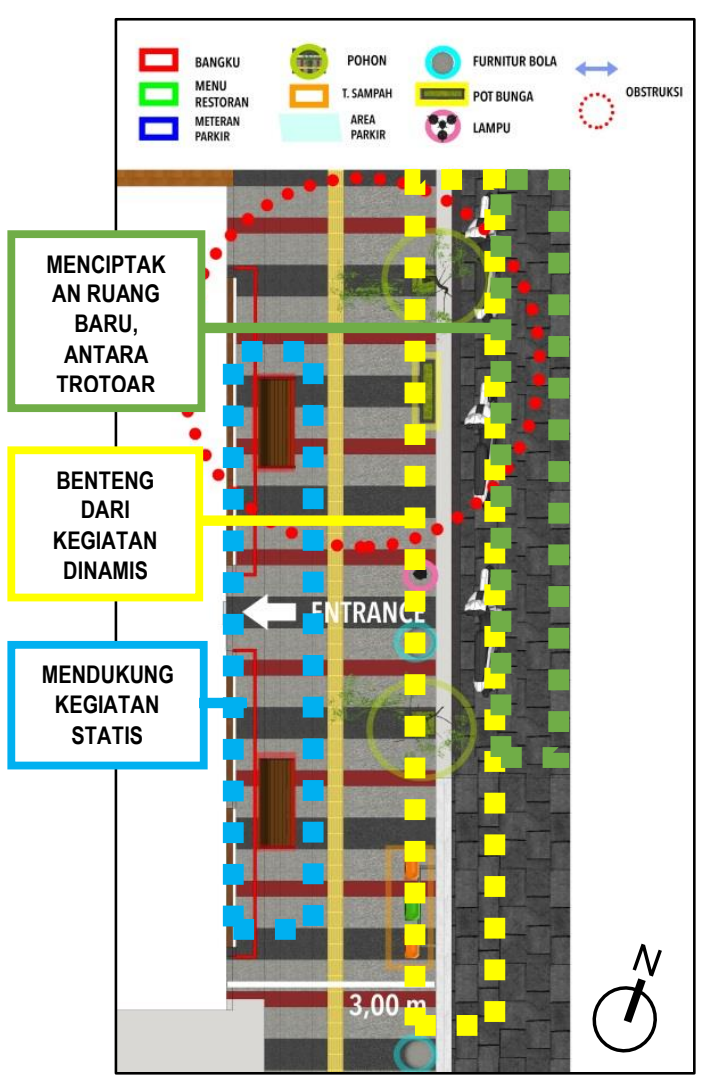

Gambar Error! No text of specified style in document..12. Hambatan pada Gejala Penghambatan PP1 yang memberi dampak secara tidak langsung

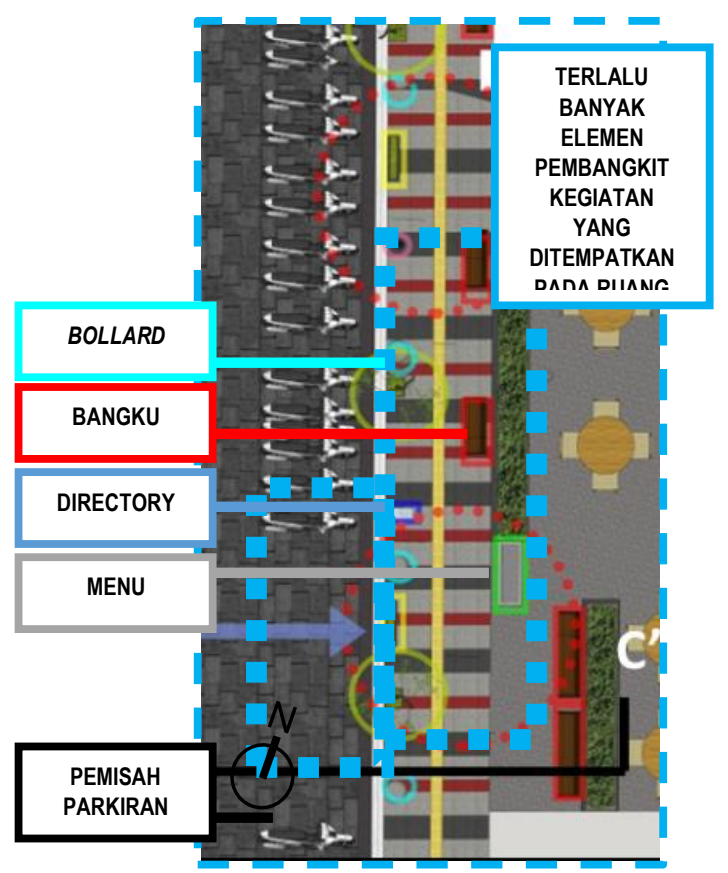

Penghambatan pada Gejala Penghambatan PK1 terjadi karena adanya hambatan bergerak berupa pedestrian menyeberang, sehingga pejalan kaki harus menunggu giliran (PM) atau menghindar (PDS dan PKS). Hambatan tersebut terpicu oleh setting fisik, baik frontage bangunan yang menarik keramaian maupun elemen pembentuk ruang, khususnya hambatan berupa street furniture dan hambatan bergerak (informal) yang membentuk ruang sirkulasi alternatif dan benteng fisik dari kegiatan dinamis dan memicu kegiatan statis. 
Gambar Error! No text of specified style in document..13. Hambatan pada Gejala Penghambatan PP2 yang memberi dampak secara tidak langsung

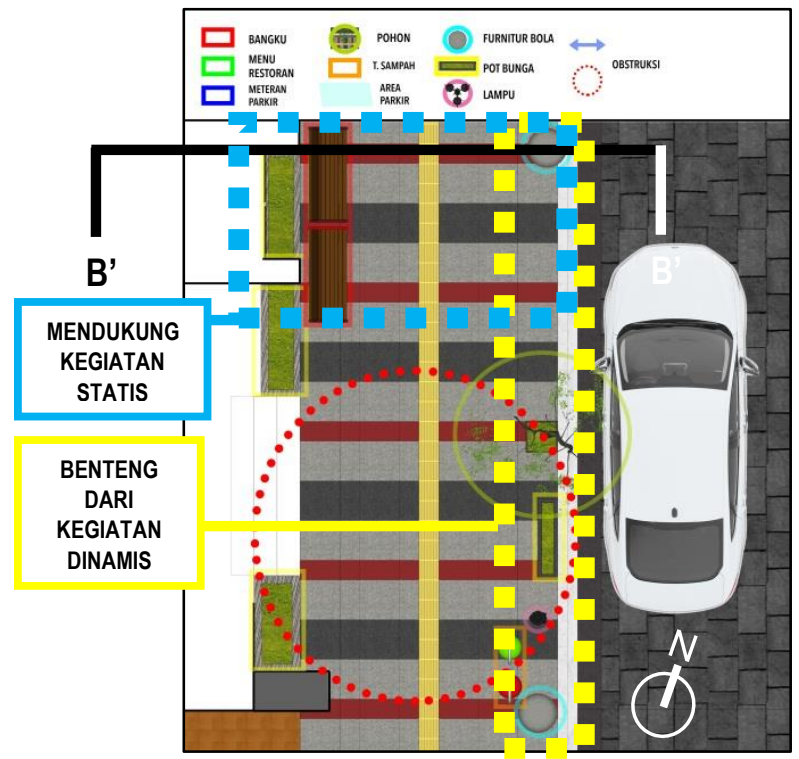

Gambar Error! No text of specified style in document..15. Hambatan pada Gejala Penghambatan PK1 yang memberi dampak secara tidak langsung

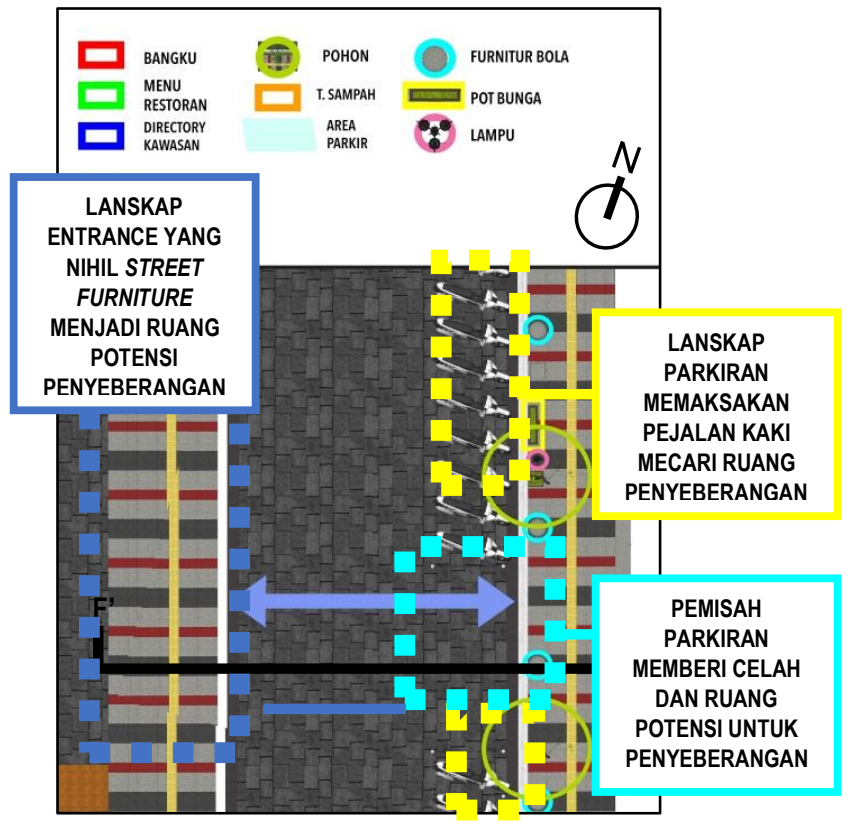

Gambar Error! No text of specified style in document..14. Hambatan pada Gejala Penghambatan PP4

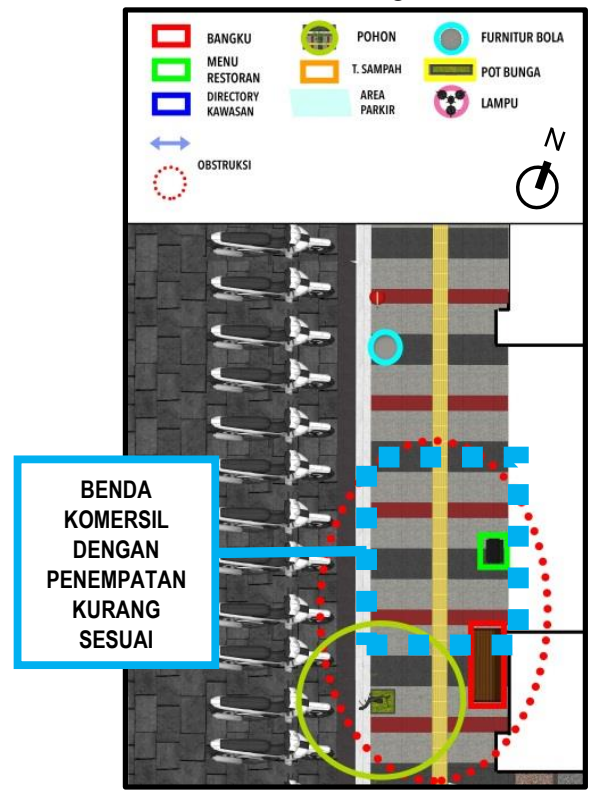

Gambar Error! No text of specified style in document..16. Gejala Penghambatan PK2 yang memberi dampak secara tidak langsung

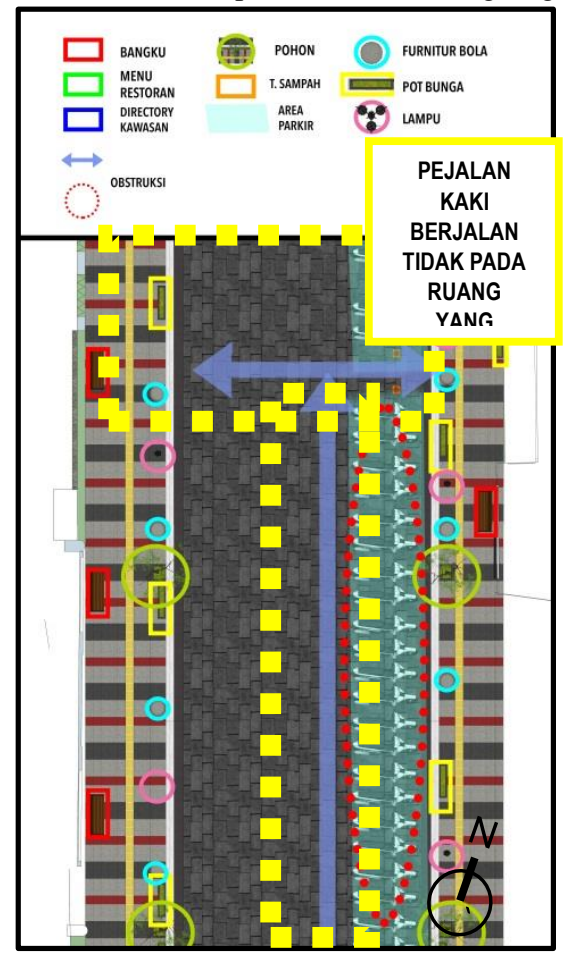

Penghambatan pada Gejala Penghambatan PK2 terjadi karena adanya hambatan bergerak berupa pedestrian menyeberang, sehingga kendaraan harus menunggu giliran (KM) atau menghindar (KDS). Hambatan tersebut tidak menunjukkan hubungan dengan setting fisik karena tidak ada elemen pembentuk ruang yang berkontribusi terhadap terjadinya gejala tersebut. Jawaban terhadap gejala tersebut, oleh karena itu, hanya dapat dijelaskan karena frontage bangunan selubung yang menarik dan luas ruang yang kapasitasinya kurang/jumlah pengunjung yang melebihi kapasitas yang telah diperuntukkan. 


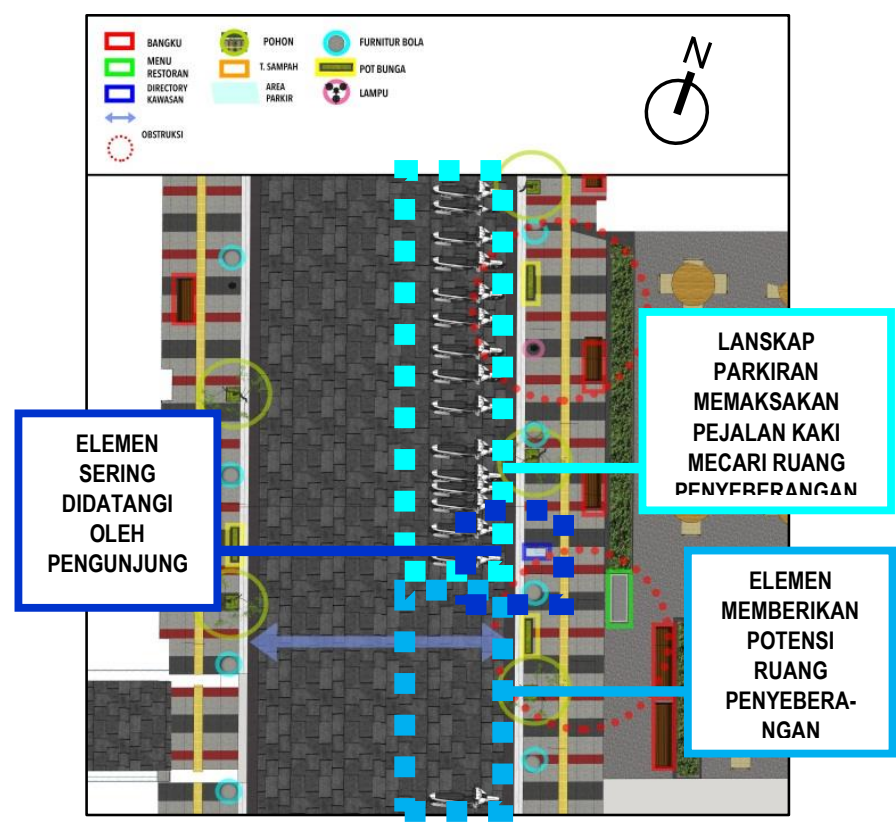

Gambar Error! No text of specified style in document.. 17. Hambatan pada Gejala Penghambatan PK3 yang memberi dampak secara tidak langsung

Tabel Error! No text of specified style in document..5. Tabel rinician identifikasi hambatan per gejala penghambatan

\begin{tabular}{|c|c|c|c|c|}
\hline \multirow{2}{*}{$\begin{array}{c}\text { Gejala } \\
\text { Penghambatan }\end{array}$} & \multicolumn{3}{|c|}{ Unit Hambatan } & \multirow{2}{*}{$\begin{array}{l}\text { Hambatan } \\
\text { (khusus) }\end{array}$} \\
\hline & SF & BK & $\mathbf{L}$ & \\
\hline PP1 & V & & & $\begin{array}{c}\text { Bangku, bollard, } \\
\text { motor/mobil }\end{array}$ \\
\hline PP2 & $\mathrm{V}$ & & & $\begin{array}{l}\text { Bangku, bollard, } \\
\text { motor/mobil }\end{array}$ \\
\hline PP3 & V & V & & $\begin{array}{l}\text { Menu restoran } \\
\text { Bangku, papan } \\
\text { informasi, menu } \\
\text { restoran, } \\
\text { pemisah } \\
\text { parkiran }\end{array}$ \\
\hline PP4 & $\mathrm{V}$ & $\mathrm{V}$ & & Menu Restoran \\
\hline PK1 & & V & & $\begin{array}{c}\text { Pemisah } \\
\text { parkiran, ruang } \\
\text { parkir dan } \\
\text { entrance mall }\end{array}$ \\
\hline PK2* & & & & - \\
\hline PK3 & $\mathrm{V}$ & V & $\mathrm{V}$ & $\begin{array}{c}\text { Papan informasi, } \\
\text { pemisah } \\
\text { parkiran }\end{array}$ \\
\hline \multicolumn{5}{|c|}{$\begin{array}{l}\text { SF }=\text { Street Furniture, } \mathrm{BK}=\text { Benda Penggunaan } \\
\text { Komersil, L = Lanskap }\end{array}$} \\
\hline
\end{tabular}

Tabel Error! No text of specified style in document..6. Tabel rincian identifikasi elemen pembentuk ruang berupa hambatan

\begin{tabular}{|c|c|c|c|c|}
\hline \multirow[b]{2}{*}{$\begin{array}{l}\text { Pengham- } \\
\text { batan }\end{array}$} & \multirow[b]{2}{*}{$\begin{array}{c}\text { Hambatan } \\
\text { (khusus) }\end{array}$} & \multicolumn{3}{|c|}{ Tipe Elemen Setting Fisik } \\
\hline & & $\begin{array}{l}\text { Semi- } \\
\text { Fixed }\end{array}$ & Fixed & Informal \\
\hline \multirow[t]{3}{*}{ PP1 } & Bangku & $\mathrm{V}$ & & \\
\hline & Bollard & & $\mathrm{V}$ & \\
\hline & Kendaraan & & & $\mathrm{V}$ \\
\hline \multirow[t]{3}{*}{ PP2 } & Bangku & $\mathrm{V}$ & & \\
\hline & Bollard & & $\mathrm{V}$ & \\
\hline & Kendaraan & & & $\mathrm{V}$ \\
\hline \multirow[t]{4}{*}{ PP3 } & Bangku & $\mathrm{V}$ & & \\
\hline & $\begin{array}{l}\text { Papan } \\
\text { Informasi }\end{array}$ & & $\mathrm{V}$ & \\
\hline & $\begin{array}{l}\text { Menu } \\
\text { Restoran }\end{array}$ & V & & \\
\hline & $\begin{array}{l}\text { Pemisah } \\
\text { Parkiran }\end{array}$ & V & & \\
\hline \multirow[t]{3}{*}{ PK1 } & $\begin{array}{l}\text { Pemisah } \\
\text { Parkiran }\end{array}$ & $\mathrm{V}$ & & \\
\hline & $\begin{array}{l}\text { Ruang } \\
\text { Parkir }\end{array}$ & & $\mathrm{V}$ & \\
\hline & $\begin{array}{l}\text { Ruang } \\
\text { entrance } \\
\text { mall }\end{array}$ & & $\mathrm{V}$ & \\
\hline PK2* & - & & & \\
\hline \multirow[t]{2}{*}{ PK3 } & $\begin{array}{l}\text { Papan } \\
\text { Informasi }\end{array}$ & $\mathrm{V}$ & & \\
\hline & $\begin{array}{l}\text { Pemisah } \\
\text { Parkiran }\end{array}$ & $\mathrm{V}$ & & \\
\hline
\end{tabular}


Penghambatan pada Gejala Penghambatan PK3 terjadi karena adanya hambatan bergerak berupa pedestrian menyeberang, kendaraan kaki harus menunggu giliran (KM) atau menghindar (KDS). Hambatan tersebut terpicu oleh setting fisik, baik frontage bangunan yang menarik keramaian maupun elemen pembentuk ruang, khususnya hambatan berupa street furniture dan hambatan berupa lanskap yang membentuk ruang menyebrang dengan menyediakan ruang terbuka untuk memasuki trotoar pada titik spesifik dan, pada titik tersebut, menyediakan street furniture yang sering didatangi.

Hasil analisa memperlihatkan bahwa bentuk hambatan paling banyak merupakan street furniture dan benda dengan penggunaan komersil. Dari total 3 unit hambatan tersebut, paling banyak merupakan elemen setting-fisik semi-fixed, yang juga, berdasarkan hasil observasi, diletakkan pada ruang untuk kegiatan tambahan. Oleh karena itu, dapat dikatakan bahwa gejala penghambatan disebabkan oleh penataan elemen-elemen tersebut yang kurang tepat, karena gejala yang terjadi pada keberadaan tiap hambatan bersifat beda dan sangat spesifik terhadap kegiatan-kegiatan yang ada pada tiap area gejala.

\subsection{AKUISISI RUANG SIRKULASI DAN OVERCROWDING RUANG}

Berdasarkan dan studi literatur, didapatkan luas ruang kegiatan efektif yang dipicu oleh kerberadaan elemen pembentuk ruang, termasuk elemen yang masuk kategori hambatan. Data tersebut lalu digunakan untuk simulasi ruang jalan dan estimasi ruang sirkulasi resultan setelah dilakukannya akuisisi. Berikut merupakan rincian ruang yang diakusisi oleh hambatan. Hasil simulasi dapat dilihat pada gambar 5.1, 5.3, 5.5, dan 5.7.

Tabel Error! No text of specified style in document..7. Rincian ruang yang diakuisi oleh elemen fisik yang teridentifikasi sebagai hambatan

\begin{tabular}{|c|c|l|}
\hline $\begin{array}{c}\text { Elemen Setting Fisik (teridentifikasi } \\
\text { sebagai hambatan) }\end{array}$ & $\begin{array}{c}\text { Ruang yang Diakuisisi } \\
\text { (pxl / m) }\end{array}$ \\
\hline \multicolumn{3}{|c|}{ Penghambatan berupa street furniture } \\
\hline Bangku & $0.86 \times 0$ & Duduk; berkumpul pada area tersebut \\
\hline Bollard & $0.86 \times 0.86$ & Duduk; berkumpul pada area tersebut \\
\hline Papan Informasi & $0.60 \times 0.45$ & Berdiri; berkumpul pada area tersebut \\
\hline \multicolumn{3}{|c|}{ Penghambatan berupa benda komersil } \\
\hline Menu Restoran & $0.60 \times 0.45$ & Berdiri \\
\hline Pemisah ruang Parkir & (variasi) & Menyeberang pada titik tersebut \\
\hline Cone & (variasi) & Menyeberang pada titik tersebut \\
\hline \multicolumn{2}{|c|}{ Penghambatan berupa Lanskap } \\
\hline Ruang Parkir & (variasi) & Memaksa untuk menyeberang pada titik \\
\hline (variasi) & Merpotensial saja \\
\hline Tatanan pada area Entrance Mall &
\end{tabular}

Hasil survey memperlihatkan bahwa deretan pejalan kaki antara 1-4 orang, namun angka 2 diambil sebagai minimum dengan pencatatan bahwa jalan digunakan untuk perjalanan 2 arah. Hasil dari perbandingan ruang sirkulasi per orang yang didapatkan dapat dibandingkan dengan tingkat overcrowding.

Gejala Penghambatan PP1, memiliki laju yang constrained ketika terdapat 2-3 orang dan congested ketika memiliki 4 orang. Dengan hasil tersebut, maka dapat dinyatakan bahwa ruang masih kurang nyaman.

Gejala Penghambatan PP2, memiliki laju yang constrained. Dengan hasil tersebut, maka dapat dinyatakan bahwa ruang masih kurang nyaman.

Gejala Penghambatan PP3, memiliki laju yang constrained, congested, dan jammed. Gejala tersebut memiliki luas paling kecil, dan terjawab dengan setting fisik karena juga 
merupakan area gejala pengaruh hambatan paling banyak. Dengan hasil tersebut, maka dapat dinyatakan bahwa ruang masih tidak nyaman.

Gejala Penghambatan PP4, memiliki laju yang constrained ketika dilalui 2-3 pejalan kaki dan congested ketika dilalui 4. Dengan hasil tersebut, maka dapat dinyatakan bahwa ruang masih kurang nyaman.

Dari hasil analisa ini, didapatkan bahwa ruang jalan masih kurang nyaman dan memiliki tingkat overcrowding yang cukup tinggi.

Gambar Error! No text of specified style in document..18. Ruang yang diakuisisi obstacle pada PP1

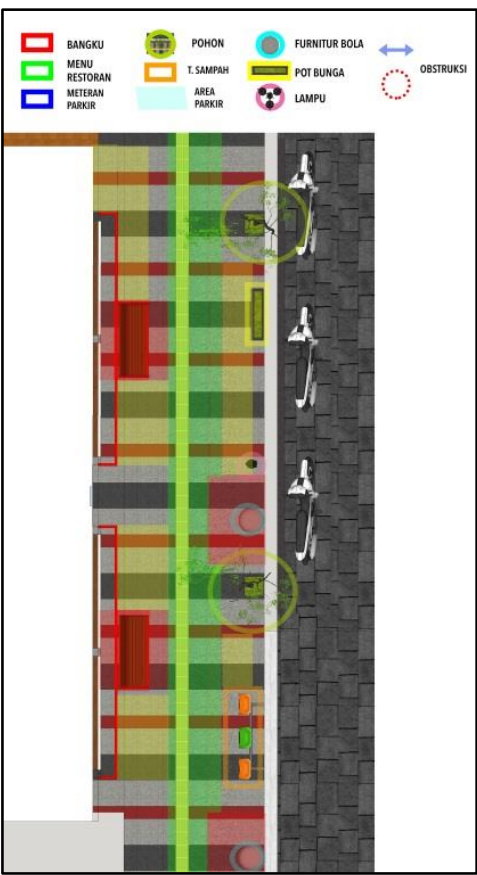

Gambar Error! No text of specified style in document..20. Ruang yang diakuisisi obstacle pada PP2

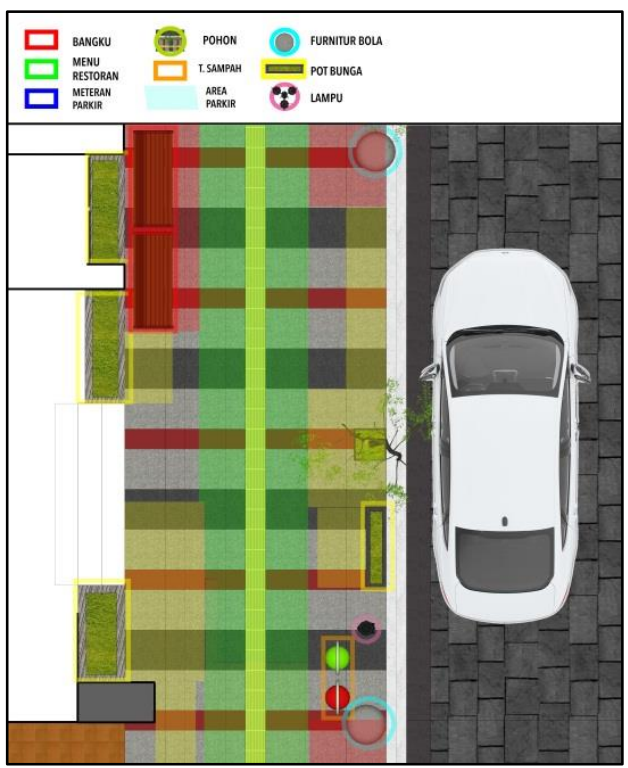

Gambar Error! No text of specified style in document..19. Luas ruang dengan kegiatan titik Penghambatan PP1

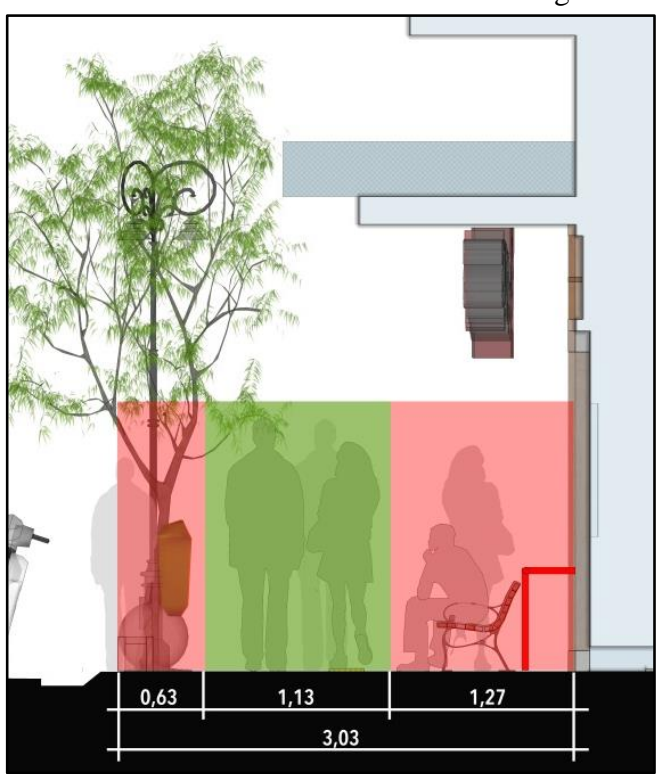

Gambar Error! No text of specified style in document..21. Luas ruang dengan kegiatan khusus berdiri titik Penghambatan PP2

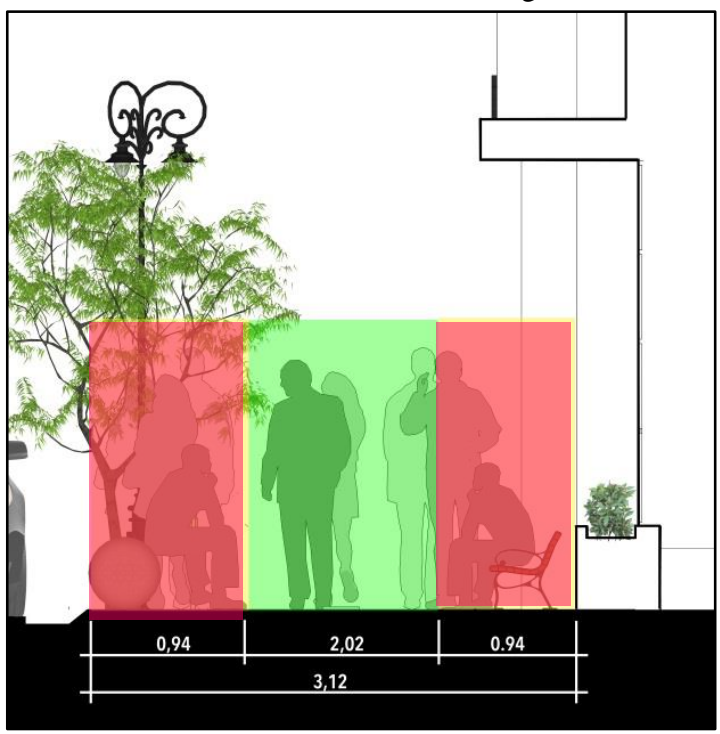


Gambar Error! No text of specified style in document..22. Ruang yang diakuisisi obstacle pada PP3

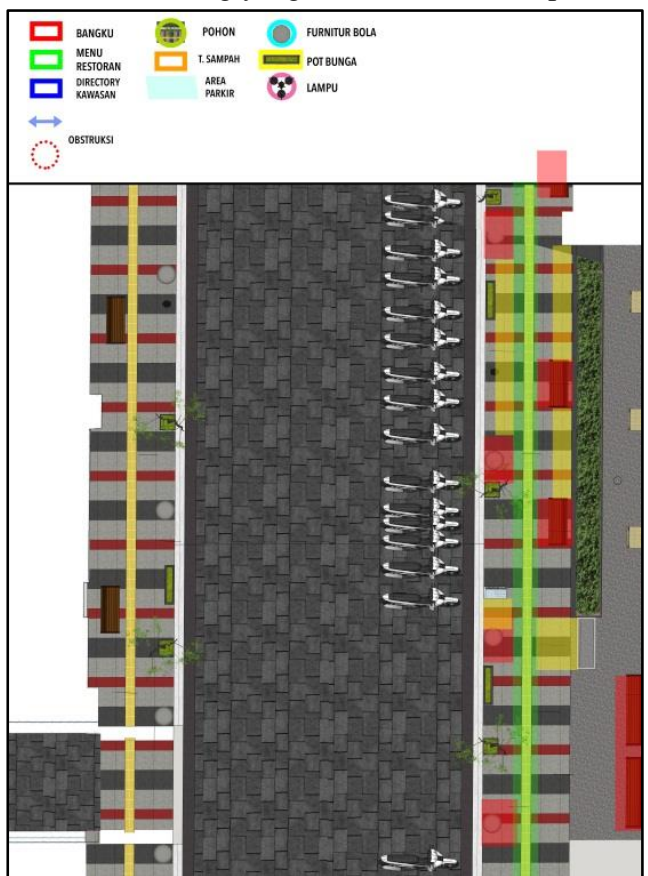

Gambar Error! No text of specified style in document..24. Ruang yang diakuisisi obstacle pada PP3

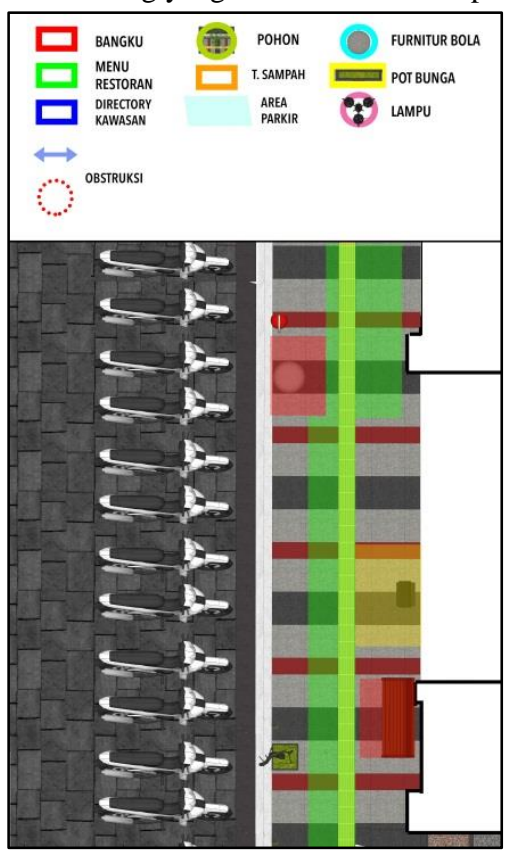

Tabel Error! No text of specified style in document..8. Kesimpulan tingkat overcrowding tiap gejala penghambatan

\begin{tabular}{|c|c|c|c|}
\hline $\begin{array}{c}\text { Gejala } \\
\text { Pengham- } \\
\text { batan }\end{array}$ & Luas & Jumlah & Tingkat Over \\
& Crkulasi & Pejalan & Crowding \\
& & Kaki & \\
& & $(2$ & \\
Arah $)$ & \\
\hline
\end{tabular}

Gambar Error! No text of specified style in document..23. Luas ruang dengan kegiatan khusus berdiri titik Penghambatan PP3

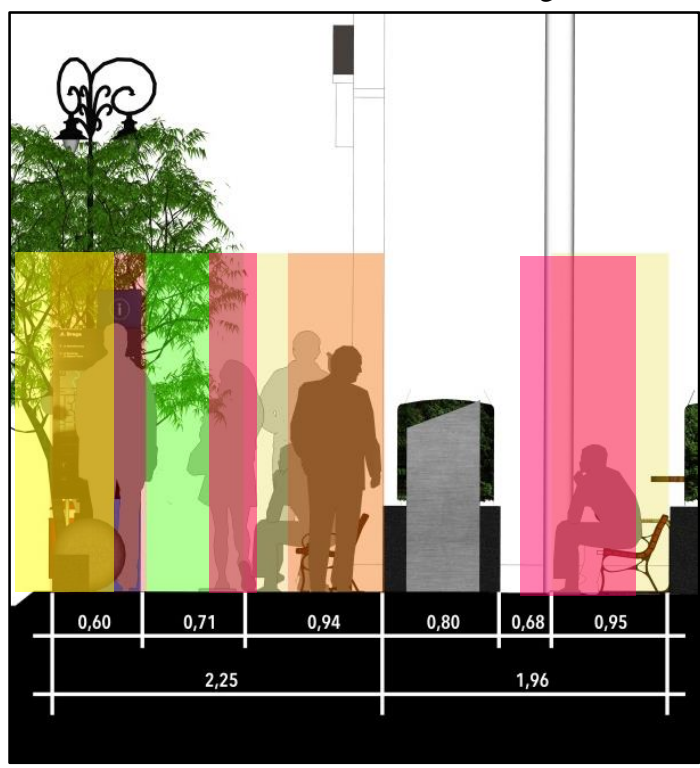

Gambar Error! No text of specified style in document..25. Luas ruang dengan kegiatan titik Gejala Penghambatan PP4

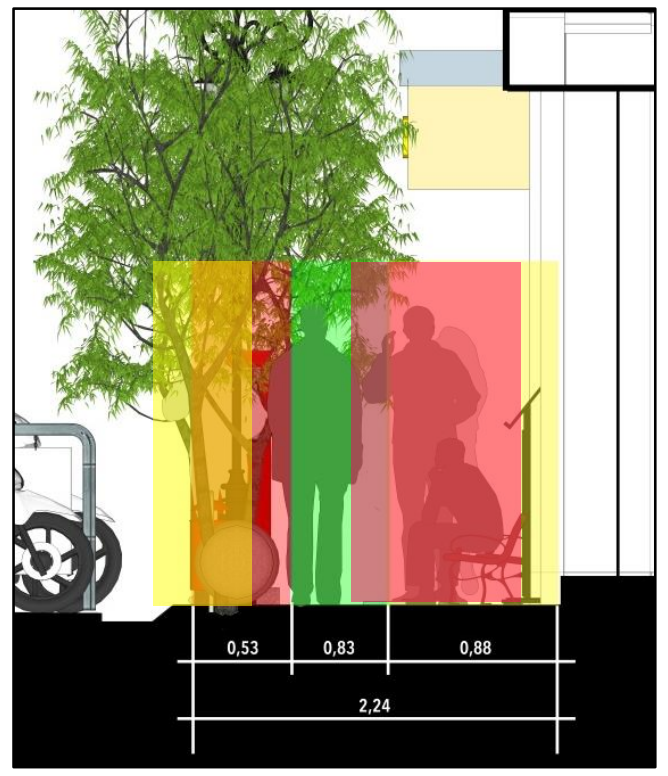

Tabel Error! No text of specified style in document..9. Kesimpulan tingkat overcrowding tiap gejala penghambatan

\begin{tabular}{|c|c|c|c|c|}
\hline \multirow{2}{*}{$\begin{array}{c}\text { Gejala } \\
\text { Pengham- } \\
\text { batan }\end{array}$} & \multicolumn{3}{|c|}{ Tingkat Overcrowding } & \multirow{2}{*}{ Penjelasan } \\
\cline { 2 - 4 } & Imp & Cons & Cong & Jam \\
\end{tabular}




\begin{tabular}{|c|c|c|c|}
\hline PP1 & \multirow{3}{*}{1,13} & 2 & CONSTRAINED \\
\cline { 3 - 4 } & & 3 & CONSTRAINED \\
\cline { 3 - 4 } & & 4 & CONGESTED \\
\hline \multirow{2}{*}{ PP2 } & \multirow{3}{*}{1,24} & 2 & CONSTRAINED \\
\cline { 3 - 4 } & & 3 & CONSTRAINED \\
\cline { 3 - 4 } & \multirow{3}{*}{0,71} & 4 & CONSTRAINED \\
\hline & & 3 & CONSTRAINED \\
\hline & & 4 & CONGESTED \\
\hline \multirow{2}{*}{ PP4 } & \multirow{3}{*}{0,83} & 2 & CONSTRAINED \\
\cline { 3 - 4 } & & 3 & CONGESTED \\
\cline { 3 - 4 } & & 4 & CONGESTED \\
\hline
\end{tabular}

\begin{tabular}{|c|c|c|c|c|l|}
\hline PP1 & & $\mathrm{V}$ & $\mathrm{V}$ & & Jalan padat \\
\hline PP2 & $\mathrm{V}$ & $\mathrm{V}$ & $\mathrm{V}$ & & $\begin{array}{l}\text { Terlalu padat } \\
\text { kecuali hanya } \\
\text { ada dua } \\
\text { pejalan kaki } \\
\text { yang berjalan } \\
\text { bersampingan }\end{array}$ \\
\hline PP3 & & $\mathrm{V}$ & $\mathrm{V}$ & $\mathrm{V}$ & $\begin{array}{l}\text { Jalan sangat } \\
\text { padat }\end{array}$ \\
\hline PP4 & & $\mathrm{V}$ & $\mathrm{V}$ & & Jalan padat \\
\hline $\begin{array}{l}\text { Imp = Impeded, Cons } \\
\text { = Constrained, Cong }=\text { Congested, Jam }\end{array}$ \\
\hline
\end{tabular}

\section{KESIMPULAN}

Berdasarkan analisa dapat ditarik kesimpulan bahwa (1) Gejala Penghambatan yang terjadi dipengaruhi oleh hambatan baik secara langsung maupun dari kegiatan yang dipicunya. Gejala penghambatan yang terjadi diantara lain merupakan aksi menghindar, menunggu, dan menggunakan ruang jalan sebagai alternatif sirkulasi; (2) hasil ruang efektif kegiatan yang mengalami penghambatan paling banyak menghasilkan tingkat overcrowding constrained dan congested, dan satu dengan tingkat jammed. Hasil ini menunjukkan bahwa tingkat kenyamanan pejalan kaki masih kurang baik dan dapat diperbaiki, sebagaimana 3 tingkatan yang didapatkan merupakan 3 tingkat terpadat diantara 6 kriteria tingkat overcrowding; (3) dari total 7 Gejala Penghambatan, 6 gejala dapat dikaitkan dengan elemen pembentuk ruang, sehingga dapat dinyatakan bahwa gejala-gejala tersebut terjadi karena adanya hambatan atau terpengaruhi oleh hambatan; dan (4) dari total 3 tipe unit hambatan dengan aspek semi-fixed, fixed, dan informal, mayoritas hambatan merupakan elemen street furniture dan benda penggunaan komersil yang sifatnya semi-fixed.

Dengan pointer tersebut, juga didapatkan kesimpulan berupa kritik dan evaluasi terhadap setting fisik jalan, di mana:

1. Terjadinya gejala penghambatan pada kegiatan berjalan banyak disebabkan oleh adanya tempat duduk dan potensi ekspansi kegiatan duduk tersebut ke sisi elemen setting fisik pemisah jalan dan trotoar. Adanya elemen-elemen pada dua sisi trotoar mengakibatkan kegiatan berada pada dua sisi tersebut, sehingga pejalan kaki yang melewati harus melewati keramaian hasil ekspansi ruang. Street furniture bukan elemen negatif yang harus dikeluarkan dari jalan ruang, namun ada baiknya jika tatanannya direncanakan sehingga terbentuk ruang-ruang kegiatan yang tetap fleksibel namun tidak mengakibatkan gejala penghambatan.

2. Terjadinya gejala penghambatan pada kegiatan laju kendaraan banyak disebabkan oleh tersedianya celah yang terbentuk oleh pemisah parkiran yang diletakkan oleh fungsi depan jalan tersebut. Khusus pada gejala G, kemungkinan terjadinya penghambatan karena ketertarikan yang kuat pada bangunan D (Upnormal).

3. Berdasarkan analisa Gejala Penghambatan, didapatkan bahwa elemen hambatan ratarata merupakan elemen setting fisik semi-fixed. Bahwa hambatan yang paling menonjol pada penelitian merupakan elemen semi-fixed menunjukkan bahwa ada kesalahan pada penataan elemen dibandingkan dengan keberadaan elemen tersebut karena elemen diletakkan untuk memenuhi fungsi baru oleh unit bangunan, kemungkinan tanpa regulasi. 
4. Dengan pernyataan-pernyataan tersebut, maka dapat dinyatakan gejala-gejala penghambatan tersebut, yaitu dengan:

a. Memindahkan posisi bangku, contohnya, ke arah dalam trotoar, sehingga posisi elemen street furniture hanya diletakkan pada satu sisi trotoar. Selain kegiatan duduk ikut berkontribusi dalam menjadi buffer antara ruang jalan dan trotoar, posisi tersebut komplementer terhadap kegiatan people watching yang merupakan salah satu kegiatan utama pada ruang publik

b. Menyediakan tempat penyeberangan dalam segmen koridor jalan

c. Menghindari menepatkan terlalu banyak elemen pembangkit kegiatan pada satu titik, seperti yang terjadi pada gejala penghambatan PP3 dan PK3

d. Memasukan regulasi tentang benda-benda (semi-fixed) untuk penggunaan unit bangunan komersil yand dapat dimasukkan ke ruang jalan

\section{DAFTAR PUSTAKA}

Carmona. 2003. Public Space Urban Space The Dimention of Urban Design. London: Architectural Press London

Moudon, Vernez. 1987. Public Streets for Public Use. Van Nostrand Reinhold.

Pushkarev, Boris. 1975. Urban Space for Pedestrian. MIT Press.

MacCormac, R. 1983. “Urban reform: MacCormac's Manifesto”. Architects journal, June, pp. 59-72. 